\title{
Peramalan Nilai Tukar Petani Subsektor Peternakan Menggunakan Fuzzy Time Series Lee
}

\author{
Mahadi Muhammad ${ }^{1 *}$, Sri Wahyuningsih ${ }^{2}$, Meiliyani Siringoringo ${ }^{3}$ \\ ${ }^{1}$ Laboratorium Ekonomi dan Bisnis, Fakultas MIPA, Universitas Mulawarman, \\ Jl. Barong Tongkok No. 4 Kampus Gunung Kelua, Samarinda 75123, Kalimantan Timur, Indonesia \\ 2,3 Program Studi Statistika, Fakultas MIPA, Universitas Mulawarman, \\ Jl. Barong Tongkok No. 4 Kampus Gunung Kelua, Samarinda 75123, Kalimantan Timur, Indonesia \\ *Penulis Korespondensi.Email: mahadimuhammad98@gmail.com
}

ABSTRAK

Fuzzy time series (FTS) Lee adalah suatu metode peramalan yang digunakan ketika jumlah data historis yang tersedia sedikit, serta tidak mensyaratkan asumsi-asumsi tertentu yang harus terpenuhi. Metode ini menggunakan data historis berupa himpunan fuzzy yang berasal dari bilangan real atas himpunan semesta pada data aktual. FTS Lee adalah perkembangan dari FTS Song dan Chissom, FTS Cheng, serta FTS Chen. Pada penelitian ini dibahas penerapan FTS Lee pada data Nilai Tukar Petani Subsektor Peternakan (NTPT) di Kalimantan Timur. Tujuan penelitian ini adalah memperoleh hasil peramalan NTPT di Kalimantan Timur pada bulan Januari 2020 dengan menggunakan FTS Lee. Langkah awal dalam penelitian ini yaitu menentukan himpunan semesta pembicaraan, langkah kedua menentukan banyaknya himpunan fuzzy, langkah ketiga mendefinisikan derajat keanggotaan himpunan fuzzy terhadap $A_{i}$ dan melakukan fuzzyfikasi pada data aktual, langkah keempat membuat fuzzy logical relationship, langkah kelima membuat fuzzy logical relationship group, langkah keenam melakukan defuzzyfikasi sehingga diperoleh hasil peramalan, serta dilanjutkan dengan menghitung nilai mean absolute percentage error. Hasil penelitian menunjukkan bahwa peramalan menggunakan FTS Lee pada bulan Januari 2020 adalah 110,25 . Nilai mean absolute percentage error pada hasil peramalan dengan menggunakan FTS Lee adalah sangat baik.

Kata Kunci:

Fuzzy Time Series Lee; Nilai Tukar Petani; Peramalan

ABSTRACT

Lee's Fuzzy time series (FTS) is a forecasting method that is used when the number of historical data that available was small and does not require certain assumptions to be fulfilled. This method uses historical data in the form of fuzzy sets derived from real numbers over the set of universes in the actual data. FTS Lee is a development of FTS Song and Chissom, FTS Cheng, and FTS Chen. This research discusses the application of FTS Lee to the Exchange Rate of Farmers Subsectors Farm (ERFSF) in Kalimantan Timur. The purpose of this study was to obtain the results of ERFSF forecasting in Kalimantan Timur in January 2020 using FTS Lee. The first step during research is to determine the set of speech universes, the second step is to determine the number of fuzzy sets, the third step is to define the degree of fuzzy association membership and fuzzification on the actual data, the fourth step is to create a fuzzy logical relationship, the fifth step is to create a fuzzy logical

e-ISSN: 2656-1344 (C) 2021 M. Muhammad, S. Wahyuningsih, M. Siringoringo | Under the license CC BY-NC 4.0 Received: 30 April 2020 | Accepted: 5 September 2020 | Online: 2 January 2021 
relationship group, the sixth step is to perform defuzzification in order to obtain forecasting results, and continue by calculating the mean absolute percentage error value. The results showed that forecasting using FTS Lee in January 2020 was 110,25. The mean absolute percentage error value in forecasting results using FTS Lee is very good.

Keywords:

Fuzzy Time Series Lee; Nilai Tukar Petani; Forecasting

Format Sitasi:

M. Muhammad, S. Wahyuningsih and M. Siringoringo, "Peramalan Nilai Tukar Petani Subsektor Peternakan Menggunakan Fuzzy Time Series Lee," Jambura J. Math., vol. 3, no. 1, pp. $1-15,2021$

\section{Pendahuluan}

Peramalan merupakan salah satu cara untuk meramalkan suatu nilai pada masa yang akan datang dengan memperhatikan data masa lalu maupun data masa kini [1]. Peramalan disebabkan oleh adanya jangka waktu antara kebutuhan mendatang dengan peristiwa itu sendiri [2]. Metode dalam analisis runtun waktu memiliki beberapa pilihan yang dapat digunakan dalam meramalkan data, seperti ARIMA, SARIMA, Smoothing, fungsi transfer dan sebagainya. Metode-metode tersebut memiliki kelemahan yaitu membutuhkan banyak data historis dan mensyaratkan asumsiasumsi tertentu yang harus dipenuhi, seperti metode ARIMA dan SARIMA. Metode yang berkembang untuk mengatasi kelemahan-kelemahan pada metode peramalan sebelumnya ialah metode fuzzy time series (FTS) [3].

FTS merupakan metode peramalan yang menggunakan data berupa himpunan fuzzy yang berasal dari bilangan real atas himpunan semesta pada data aktual. Himpunan fuzzy digunakan untuk menggantikan data historis yang akan diramalkan sehingga peramalan FTS tidak memerlukan data historis dalam jumlah banyak [4]. FTS Lee adalah perkembangan dari FTS Song dan Chissom, FTS Cheng, serta FTS Chen untuk meramalkan suatu nilai di masa yang akan datang [5]. FTS Lee digunakan untuk peramalan yang bersifat jangka pendek dengan pola data stasioner maupun nonstasioner. Penerapan FTS Lee salah satunya akan dilakukan untuk meramalkan Nilai Tukar Petani Subsektor Peternakan (NTPT) di Kalimantan Timur.

NTPT merupakan salah satu alat ukur atau indikator yang digunakan untuk menilai tingkat kesejahteraan petani subsektor peternakan. NTPT dibagi menjadi tiga yaitu NTPT $>100$, berarti petani subsektor peternakan mengalami peningkatan dalam hal perdagangan. NTPT $=100$, berarti petani subsektor peternakan tidak mengalami peningkatan maupun penurunan dalam hal perdagangan. NTPT $<100$, berarti petani subsektor peternakan mengalami penurunan dalam hal perdagangan [6].

NTPT di Kalimantan Timur mengalami peningkatan terbesar di Indonesia pada bulan Desember 2017 yaitu sebesar 1,51\% atau 106,30 [7]. Berdasarkan data tersebut dapat diketahui bahwa penduduk Provinsi Kalimantan Timur masih menggantungkan hidupnya pada subsektor peternakan. NTPT berperan penting untuk mengetahui tingkat kesejahteraan petani subsektor peternakan sehingga perlu dilakukan peramalan. Peramalan ini menjadi tolak ukur bagi pemerintah dan petani subsektor peternakan dalam membuat kebijakan untuk meningkatkan kesejahteraan petani subsektor peternakan di Provinsi Kalimantan Timur.

Metode FTS Lee untuk peramalan pernah diteliti oleh Handayani dan Anggriani [8] untuk meramalkan harga emas. Berdasarkan Hasil peramalan tersebut diperoleh 
metode FTS Lee lebih baik dibandingkan metode FTS Chen. Penelitian selanjutnya dilakukan oleh Tamrin, et.al [9] untuk meramalkan jumlah ikan. Hasil peramalan tersebut diperoleh metode FTS Lee lebih baik dibandingkan metode FTS Chen. Penelitian Nilai Tukar Petani (NTP) sebelumnya pernah dilakukan oleh beberapa peneliti namun dengan menggunakan metode yang berbeda. Salah satunya adalah penelitian yang dilakukan oleh Istiqomah [10] dengan hasil metode ARIMA lebih baik dibandingkan dengan metode exponential smoothing. Penelitian NTP lainnya dilakukan oleh Desvina dan Meijer [11], penelitian tersebut menunjukkan bahwa metode ARCH lebih baik dibandingkan metode GARCH.

Pada penelitian ini digunakan metode FTS Lee untuk meramalkan NTPT di Kalimantan Timur. Penggunaan metode tersebut karena FTS Lee dapat meramalkan data dengan jumlah data historis yang tersedia sedikit dan tanpa mensyaratkan asumsi-asumsi tertentu yang harus terpenuhi, serta FTS Lee menghasilkan nilai akurasi yang lebih baik dari pada metode FTS Chen. Hal ini disebabkan karena FTS Lee tetap menghitung fuzzy logical relationship group yang sama. Sehingga, penelitian ini bertujuan untuk meramalkan NTPT di Kalimantan Timur pada bulan Januari 2020 dengan menggunakan metode Fuzzy Time Series Lee.

\section{Metode}

Data yang digunakan merupakan data sekunder yang diperoleh dari Badan Pusat Statistik (BPS) Provinsi Kalimantan Timur. Data penelitian adalah nilai tukar petani subsektor peternakan (NTPT) di Kalimantan Timur. Data tersebut merupakan data deret waktu bulanan dari bulan Juli 2017 hingga Desember 2019. Teknik analisis yang digunakan adalah metode fuzzy time series Lee.

\subsection{Metode Fuzzy Time Series Lee}

Fuzzy time series (FTS) adalah sebuah konsep baru yang diusulkan oleh Song dan Chissom (1993) berdasarkan teori himpunan fuzzy dan konsep variabel linguistik dan aplikasinya oleh zadeh [12]. FTS adalah metode peramalan dengan menggunakan kecerdasan buatan untuk mengolah data aktual yang dibentuk ke dalam nilai-nilai linguistik yang dikenal dengan himpunan fuzzy [13]. FTS memiliki perbedaan utama dengan peramalan konvensional time series lainnya yaitu terletak pada nilai yang digunakan. FTS menggunakan nilai-nilai linguistik yang dikenal dengan himpunan fuzzy [14].

Himpunan fuzzy adalah himpunan dimana nilai keanggotaan dari setiap elemennya tidak mempunyai batasan yang jelas [15]. Himpunan fuzzy memiliki lebih dari 2 nilai keanggotaan dalam rentang 0 sampai dengan 1, seperti : sangat buruk, buruk, cukup, baik dan sangat baik [16]. FTS Lee adalah perkembangan dari FTS Song dan Chissom, FTS Cheng, serta FTS Chen untuk meramalkan suatu nilai di masa yang akan datang [5]. FTS Lee digunakan untuk peramalan yang bersifat jangka pendek dengan pola data stasioner maupun non-stasioner. Langkah-langkah peramalan dengan menggunakan FTS Lee adalah sebagai berikut [5]:

a) Langkah pertama: menentukan $U$ atau himpunan semesta pembicaraan data aktual dengan rumus berikut:

$$
U=\left[D_{\min }-Z_{1}, D_{\max }+Z_{2}\right]
$$


dimana nilai $Z_{1}$ dan $Z_{2}$ adalah sembarang bilangan positif. Sedangkan $D_{\min }$ adalah nilai data terkecil dan $D_{\max }$ adalah nilai data terbesar.

b) Langkah kedua: menentukan banyaknya himpunan fuzzy dengan langkah sebagai berikut:

1. Menentukan $R$ atau panjang interval $U$ dengan rumus sebagai berikut:

$$
R=D_{\max }+Z_{2}-D_{\min }-Z_{1}
$$

2. Hitung mean atau rata-rata nilai selisih (lag) absolute dengan rumus sebagai berikut:

$$
\text { mean }=\frac{\sum_{t=1}^{N-1}\left|\left(\mathrm{D}_{t+1}\right)-\mathrm{D}_{t}\right|}{N-1}
$$

dimana nilai $D_{t}$ adalah data waktu ke- $t, D_{t+1}$ adalah data waktu ke-(t+1), dan $N$ adalah jumlah data atau banyaknya data.

3. Menentukan $K$ atau basis interval, hasil dari proses (2.3) dibagi 2 dengan rumus sebagai berikut:

$$
K=\frac{\text { mean }}{2}
$$

Nilai basis interval beserta jangkauan pada setiap basisnya dapat dilihat secara lengkap pada Tabel 1.

Tabel 1. Basis interval

\begin{tabular}{cc}
\hline Jangkauan & Basis \\
\hline $0,10-1$ & 0,10 \\
$1,10-10$ & 1 \\
$11-100$ & 10 \\
$101-1000$ & 100 \\
$1001-10000$ & 1000 \\
\hline
\end{tabular}

4. Setelah mendapat nilai basis interval maka nilai jangkauan dari basis tersebut dapat digunakan sebagai panjang interval himpunan fuzzy.

5. Menentukan $n$ atau banyaknya himpunan fuzzy dengan rumus sebagai berikut:

$$
n=\frac{R}{K}
$$

6. Mencari $m$ atau nilai tengah himpunan fuzzy dengan rumus sebagai berikut:

$$
m_{i}=\frac{\left(\text { Batas bawah } u_{i}+\text { Batas atas } u_{i}\right)}{2}
$$


dimana $u_{i}$ adalah himpunan fuzzy ke-i, dan $m_{i}$ adalah nilai tengah himpunan fuzzy ke-i.

c) Langkah ketiga: mendefinisikan derajat keanggotaan himpunan fuzzy terhadap $A_{i}$ ( $\left.\mu_{A_{i}}\left(u_{i}\right)\right)$ dan melakukan fuzzyfikasi pada data aktual. Menurut Sutojo, et.al [17], fuzzyfikasi adalah proses untuk mengubah input sistem yang mempunyai nilai tegas (numeris) menjadi variabel linguistik menggunakan nilai keanggotaan yang disimpan dalam basis pengetahuan fuzzy. Banyaknya variabel linguistik dalam himpunan fuzzy tidak memiliki batasan tertentu. Pendefinisian himpunan fuzzy pada $A_{i}\left(A_{i}\right.$ adalah fuzzyfikasi ke-i) melalui nilai keanggotaan. Nilai keanggotaan dari himpunan fuzzy $u_{i}$ disederhanakan dengan nilai diantara 0, 0,5, dan 1, dimana $1 \leq i \leq n, n$ adalah banyaknya himpunan fuzzy. Pendefinisian derajat keanggotaan himpunan fuzzy terhadap $A_{i}$ dapat dilihat pada Persamaan 7.

$$
\mu_{A_{i}}\left(u_{i}\right)=\left\{\begin{array}{cc}
1 & \text { jika } i=i \\
0,5 & \text { jika } i=i-1 \text { atau } i=i+1 \\
0 & \text { yang lainnya }
\end{array}\right.
$$

Dari Persamaan 7 tersebut menghasilkan pendefinisian himpunan fuzzy sebagai berikut:

$$
\begin{aligned}
& \mu_{A_{1}}\left(u_{i}\right)=1 / u_{1}+0,5 / u_{2}+0 / u_{3}+\cdots+0 / u_{n} \\
& \mu_{A_{2}}\left(u_{i}\right)=0,5 / u_{1}+1 / u_{2}+0,5 / u_{3}+\cdots+0 / u_{n} \\
& \mu_{A_{3}}\left(u_{i}\right)=0 / u_{1}+0,5 / u_{2}+1 / u_{3}+\cdots+0 / u_{n} \\
& \mu_{A_{n}}\left(u_{i}\right)=0 / u_{1}+0 / u_{2}+0 / u_{3}+\cdots+1 / u_{n}
\end{aligned}
$$

di mana $u_{i}(i=1,2, \ldots, n)$ adalah himpunan fuzzy ke- $i$ dan bilangan yang diberi simbol "/" menyatakan nilai keanggotaan $u_{i}$ dalam suatu $A_{i}(i=1,2, \ldots, n)$ yang nilainya ialah $0,0,5$, atau 1 .

d) Langkah keempat: membuat Fuzzy Logical Relationship (FLR) berdasarkan data aktual. Tahap ini menentukan relasi logika fuzzy yaitu $A_{i} \rightarrow A_{j}$. $A_{i}$ merupakan current state $D_{(t-1)}$ dan $A_{j}$ adalah next state pada waktu ke $D_{t}$. FLR menghubungkan relasi antara nilai linguistik yang ditentukan berdasarkan tabel fuzzyfikasi yang didapat sebelumnya.

e) Langkah kelima: membuat Fuzzy Logical Relationship Group (FLRG) model Lee. FLRG dilakukan dengan cara mengelompokkan fuzzyfikasi yang memiliki current state yang sama lalu dikelompokkan menjadi satu grup pada next state. Pada FTS 
Lee, semua FLR dikelompokkan menjadi FLRG yang saling berhubungan. Misal, $A_{1}$ : $A_{1} \rightarrow A_{2}, \quad A_{1} \rightarrow A_{2}$ dan $A_{1} \rightarrow A_{3}$. Dari 3 fuzzy logical relationship (FLR) dapat dikelompokkan menjadi $A_{1} \rightarrow A_{2}, A_{2}, A_{3}$, Lee akan menghasilkan $A_{1} \rightarrow A_{2}, A_{1} \rightarrow A_{2}$ dan $A_{1} \rightarrow A_{3}$, menurut Lee $A_{1} \rightarrow A_{2}, \quad A_{1} \rightarrow A_{2}$ dapat mempengaruhi nilai peramalan maka nilai tersebut harus dihitung.

f) Langkah keenam: melakukan defuzzyfikasi, menurut Sutojo, et.al [17], defuzzyfikasi adalah mengubah output fuzzy yang diperoleh dari aturan-aturan logika fuzzy menjadi nilai tegas menggunakan nilai keanggotaan yang sesuai dengan saat dilakukan fuzzyfikasi. Pada tahap ini, fuzzy ouput akan diubah menjadi nilai tegas (numeris) untuk menghasilkan nilai peramalan. Aturan dalam melakukan defuzzyfikasi pada model Lee adalah :

Aturan 1 : jika hasil fuzzyfikasi pada tahun ke $t$ adalah $A_{j}$ dan terdapat fuzzyfikasi yang tidak mempunyai relasi logika fuzzy, misal $A_{i} \rightarrow \varnothing$, dimana nilai maksimum dari nilai keanggotaan $A_{i}$ berada pada interval $u_{i}$ dan nilai tengah $u_{i}$ adalah $m_{i}$, maka hasil peramalan $\hat{y}_{t}^{(1)}$ adalah sebagai berikut :

$$
\hat{y}_{t}^{(1)}=m_{i}
$$

Aturan 2 : jika hasil fuzzyfikasi tahun ke $t$ adalah $A_{j}$ dan hanya terdapat satu FLR pada FLRG, misalnya $A_{i} \rightarrow A_{j}$ dimana $A_{i}$ dan $A_{j}$ adalah fuzzyfikasi dan nilai maksimum dari nilai keanggotaan $A_{j}$ berada pada interval $u_{j}$ dan nilai tengah dari $u_{j}$ adalah $m_{j}$, maka hasil peramalan $\hat{y}_{t}^{(1)}$ adalah sebagai berikut:

$$
\hat{y}_{t}^{(1)}=m_{j}
$$

Aturan 3 : jika hasil fuzzyfikasi tahun ke $t$ adalah $A_{j}, A_{k}, \ldots, A_{l}$ memiliki beberapa FLR ( $p$ ) pada FLRG, misalnya $A_{i} \rightarrow A_{j}, A_{j}, A_{k}, A_{k}, \ldots, A_{l}$ dimana $A_{j}, A_{j}, A_{k}, A_{k}, \ldots$, $A_{l}$ adalah fuzzyfikasi dimana nilai maksimum dari nilai keanggotaan $A_{j}, A_{j}, A_{k}, A_{k}$, $\ldots, A_{l}$ berada pada interval $u_{j}, u_{j}, u_{k}, u_{k}, \ldots, u_{l}$ dan $m_{j}, m_{j}, m_{k}, m_{k}, \ldots, m_{l}$ adalah nilai tengah, maka hasil peramalan $\hat{y}_{t}^{(1)}$ adalah sebagai berikut:

$$
\hat{y}_{t}^{(1)}=\frac{2}{p} m_{j}+\frac{2}{p} m_{k}+\ldots+\frac{1}{p} m_{l}
$$

g) Langkah ketujuh: Menghitung ketepatan nilai peramalan dengan menggunakan mean absolute percentage error (MAPE). Nilai MAPE yang semakin kecil maka semakin akurat teknik peramalan tersebut dan sebaliknya. Hasil peramalan sangat baik jika memiliki nilai MAPE kurang dari 10\% dan mempunyai kemampuan peramalan yang baik jika nilai MAPE kurang dari 20\% [18]. Rumus MAPE adalah 
Peramalan Nilai Tukar Petani Subsektor Peternakan Menggunakan ...

$$
M A P E=\left(\frac{1}{N} \sum_{t=1}^{N} \frac{\left|D_{t}-\hat{y}_{t}^{(m)}\right|}{D_{t}}\right) \times 100 \%
$$

dimana:

MAPE : Mean Absolute Percentage Error

$N \quad$ : jumlah data

$D_{t} \quad$ : data waktu ke- $t$

$\hat{y}_{t}^{(m)} \quad$ : nilai peramalan orde ke- $m$ periode ke- $t$

\section{Hasil dan Pembahasan}

\subsection{Time Series Plot NTPT di Kalimantan Timur}

Time series plot digunakan untuk melihat pergerakan pola data, serta untuk melihat titik terendah dan tertinggi dari pola data tersebut. Time series plot data NTPT di Kalimantan Timur dari bulan Juli 2017 hingga Desember 2019 ditampilkan pada Gambar 1.

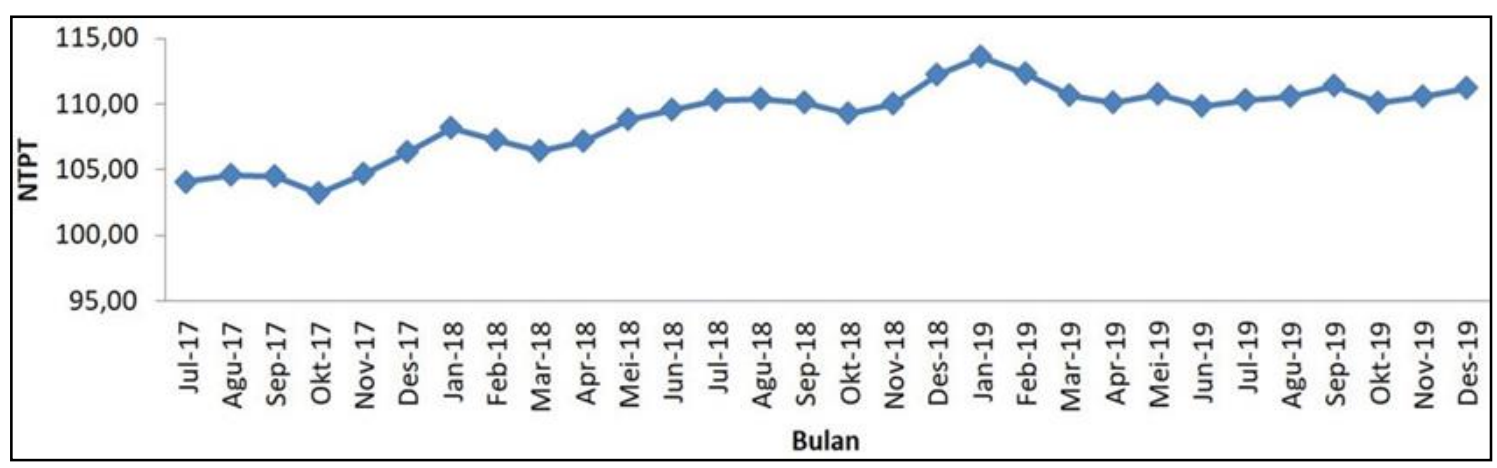

Gambar 1. Time series plot data NTPT di Kalimantan Timur

Berdasarkan Gambar 1 menunjukkan bahwa NTPT di Kalimantan Timur memiliki pola data trend naik. NTPT terendah di Kalimantan Timur terjadi pada bulan Oktober 2017 dan yang tertinggi terjadi pada bulan Januari 2019.

\subsection{Penentuan Himpunan Semesta Pembicaraan}

Data NTPT di Kalimantan Timur pada bulan Juli 2017 sampai dengan Desember 2019 memiliki NTPT terendah sebesar 103,20 dan NTPT tertinggi sebesar 113,59. Berdasarkan Persamaan (1), nilai $Z_{1}$ dan $Z_{2}$ adalah sembarang bilangan positif. Peneliti menentukan $Z_{1}=0,20$ dan $Z_{2}=0,70$. Berdasarkan Persamaan (1), himpunan semesta pembicaraan adalah sebagai berikut:

$$
\begin{aligned}
U & =\left[D_{\min }-Z_{1} ; D_{\max }+Z_{2}\right] \\
& =[103,20-0,20 ; 113,59+0,70] \\
& =[103,00 ; 114,29]
\end{aligned}
$$




\subsection{Penentuan Banyaknya Himpunan Fuzzy}

Penentuan banyaknya himpunan fuzzy pada data NTPT di Kalimantan Timur dari bulan Juli 2017 sampai dengan Desember 2019 dihitung dengan cara sebagai berikut:

1. Menghitung panjang interval semesta pembicaraan

Panjang interval semesta pembicaraan ditentukan dengan menggunakan Persamaan

(2). Berikut perhitungan panjang interval semesta pembicaraan:

$$
\begin{aligned}
R & =D_{\max }+Z_{2}-D_{\min }-Z_{1} \\
& =113,59+0,70-103,20-0,20 \\
& =11,29
\end{aligned}
$$

2. Menghitung rata-rata Selisih absolut setiap data

Rata-rata selisih absolut setiap data dicari dengan menghitung jumlah selisih absolut antara data historis pada waktu ke- $t+1$ dengan data historis ke- $t$. Jumlah selisih absolut data tersebut dibagi dengan banyaknya data dikurang 1 . Selisih absolut data historis

\begin{tabular}{|c|c|c|c|c|}
\hline No. & Tahun & Bulan & NTPT & $\left|D_{t+1}-D_{t}\right|$ \\
\hline 1 & 2017 & Juli & 104,08 & 0,48 \\
\hline 2 & 2017 & Agustus & 104,56 & 0,11 \\
\hline 3 & 2017 & September & 104,45 & 1,25 \\
\hline$\vdots$ & $\vdots$ & $\vdots$ & $\vdots$ & $\vdots$ \\
\hline \multirow[t]{3}{*}{30} & 2019 & Desember & 111,18 & - \\
\hline & $\sum_{i=1}^{N-1}$ & $-D_{t}$ & & 27,04 \\
\hline & mean & $\frac{\sum_{i=1}^{N-1}\left|D_{t+1}-D_{t}\right|}{N-1}$ & & 0,93 \\
\hline
\end{tabular}
dapat dilihat pada Tabel 2.

Tabel 2 Rata-rata selisih absolut data historis

3. Menghitung basis interval himpunan fuzzy

Hasil rata-rata selisih absolut data digunakan untuk menghitung basis interval fuzzy dengan menggunakan Persamaan (4). Berikut perhitungan basis interval himpunan fuzzy:

$$
\begin{aligned}
K & =\frac{\text { mean }}{2} \\
& =\frac{0,93}{2} \\
& =0,465 \approx 0,47
\end{aligned}
$$

Berdasarkan hasil perhitungan di atas, diperoleh nilai basis interval yaitu 0,47. Nilai basis interval sebesar 0,47 berdasarkan Tabel 1 termasuk dalam basis interval 0,10 dengan pembulatan panjang interval menjadi 0,50 . 
4. Menghitung banyaknya himpunan fuzzy

Basis interval digunakan untuk menghitung banyaknya himpunan fuzzy dengan menggunakan Persamaan (5). Berikut perhitungan banyaknya himpunan fuzzy:

$$
\begin{aligned}
n & =\frac{R}{K} \\
& =\frac{11,29}{0,5}=22,58 \approx 23
\end{aligned}
$$

Berdasarkan perhitungan banyaknya himpunan fuzzy, maka diperoleh hasil banyaknya himpunan fuzzy sebanyak 23 himpunan fuzzy. Himpunan fuzzy tersebut memiliki panjang interval yang sama yaitu 0,5 , maka $U=[103,00 ; 114,29]$ dipartisi menjadi 23 himpunan yang sama panjang yaitu $u_{i}$ dimana $i=1,2,3, \ldots, 23$. Berdasarkan partisi tersebut, maka himpunan fuzzy yang terbentuk adalah sebagai berikut:

$$
\begin{array}{lll}
u_{1}=[103,00 ; 103,50) & u_{9}=[107,00 ; 107,50) & u_{17}=[111,00 ; 111,50) \\
u_{2}=[103,50 ; 104,00) & u_{10}=[107,50 ; 108,00) & u_{18}=[111,50 ; 112,00) \\
u_{3}=[104,00 ; 104,50) & u_{11}=[108,00 ; 108,50) & u_{19}=[112,00 ; 112,50) \\
u_{4}=[104,50 ; 105,00) & u_{12}=[108,50 ; 109,00) & u_{20}=[112,50 ; 113,00) \\
u_{5}=[105,00 ; 105,50) & u_{13}=[109,00 ; 109,50) & u_{21}=[113,00 ; 113,50) \\
u_{6}=[105,50 ; 106,00) & u_{14}=[109,50 ; 110,00) & u_{22}=[113,50 ; 114,00) \\
u_{7}=[106,00 ; 106,50) & u_{15}=[110,00 ; 110,50) & u_{23}=[114,00 ; 114,50] \\
u_{8}=[106,50 ; 107,00) & u_{16}=[110,50 ; 111,00)
\end{array}
$$

\subsection{Perhitungan Nilai Tengah Himpunan Fuzzy}

Perhitungan nilai tengah himpunan fuzzy menggunakan Persamaan (6). Hasil perhitungan nilai tengah himpunan fuzzy $\left(m_{i}\right)$ secara lengkap dapat dilihat pada Tabel 3.

Tabel 3. Nilai tengah himpunan fuzzy

\begin{tabular}{llllllll}
\hline No. & $m_{i}$ & No. & $m_{i}$ & No. & $m_{i}$ & No. & $m_{i}$ \\
\hline 1 & 103,25 & 7 & 106,25 & 13 & 109,25 & 19 & 112,25 \\
2 & 103,75 & 8 & 106,75 & 14 & 109,75 & 20 & 112,75 \\
3 & 104,25 & 9 & 107,25 & 15 & 110,25 & 21 & 113,25 \\
4 & 104,75 & 10 & 107,75 & 16 & 110,75 & 22 & 113,75 \\
5 & 105,25 & 11 & 108,25 & 17 & 111,25 & 23 & 114,25 \\
6 & 105,75 & 12 & 108,75 & 18 & 111,75 & 24 & - \\
\hline
\end{tabular}

Berdasarkan Tabel 3 nilai tengah himpunan fuzzy ke-1 sampai dengan ke-23 diperoleh menggunakan Persamaan (6). Berikut contoh perhitungan nilai tengah himpunan fuzzy ke-1 $\left(m_{1}\right)$ : 


$$
\begin{aligned}
& m_{1}=\frac{\left(\text { Batas bawah } u_{1}+\text { Batas atas } u_{1}\right)}{2} \\
& m_{1}=\frac{(103,00+103,50)}{2}=103,25
\end{aligned}
$$

\subsection{Pendefinisian Derajat Keanggotaan Himpunan Fuzzy terhadap $A_{i}$ dalam Proses} Fuzzyfikasi

Pendefinisian derajat keanggotaan himpunan fuzzy terhadap $A_{i}$ didasarkan pada 23 himpunan fuzzy yang terbentuk. Diasumsikan nilai fuzzyfikasi dari variabel linguistik data NTPT di Kalimantan Timur yaitu $A_{1}, A_{2}, A_{3}, \ldots A_{23}$. Setiap himpunan fuzzy $u_{i}$ dimana $i=1,2,3 \ldots, 23$ didefinisikan terhadap $A_{i}$ dengan menggunakan Persamaan (7). Berikut pendefinisian derajat keanggotaan himpunan fuzzy terhadap $A_{i}$ :

$$
\begin{aligned}
& \mu_{A_{1}}\left(u_{i}\right)=1 / u_{1}+0,5 / u_{2}+0 / u_{3}+\cdots+0 / u_{23} \\
& \mu_{A_{2}}\left(u_{i}\right)=0,5 / u_{1}+1 / u_{2}+0,5 / u_{3}+\cdots+0 / u_{23} \\
& \mu_{A_{3}}\left(u_{i}\right)=0 / u_{1}+0,5 / u_{2}+1 / u_{3}+\cdots+0 / u_{23} \\
& \mu_{A_{23}}\left(u_{i}\right)=0 / u_{1}+0 / u_{2}+0 / u_{3}+\cdots+1 / u_{23}
\end{aligned}
$$

$u_{i}$ merupakan himpunan fuzzy ke-i dan bilangan yang diberi simbol "/" menyatakan derajat keanggotaan $u_{i}$ terhadap $A_{i}, i=1,2,3 \ldots, 23$ yang dimana nilainya adalah $0,5,1$, atau 0 . Selain itu, tanda (+) dalam pendefinisian derajat keanggotaan himpunan fuzzy terhadap $A_{i}$ di atas tidak melambangkan operasi penjumlahan, melainkan melambangkan keseluruhan unsur-unsur $u_{i}$.

Berdasarkan pendefinisian derajat keanggotaan himpunan fuzzy terhadap $A_{i}$, maka diperoleh hasil fuzzyfikasi. Hasil fuzzyfikasi secara lengkap dapat dilihat pada Tabel 4.

Tabel 4 Hasil fuzzyfikasi

\begin{tabular}{ll}
\hline Fuzzyfikasi & Nilai Linguistik \\
\hline$A_{1}$ & Sangat sangat turun drastis sekali \\
$\vdots$ & $\vdots$ \\
$A_{11}$ & Sedikit turun \\
$A_{12}$ & Moderat \\
$A_{13}$ & Sedikit naik \\
$\vdots$ & $\vdots$ \\
$A_{23}$ & Sangat sangat turun drastis sekali \\
\hline
\end{tabular}


Berdasarkan Tabel 4 maka diperoleh 23 nilai fuzzyfikasi. Misal, $A_{1}$ adalah hasil fuzzyfikasi yang diperoleh dari pendefinisian derajat keanggotaan himpunan fuzzy $\left(u_{i}\right)$ terhadap $A_{1}$. Hasil pendefinisian tersebut diperoleh derajat keanggotaan $u_{1}$ sebesar 1 , derajat keanggotaan $u_{2}$ sebesar 0,5 dan derajat keanggotaan $u_{3}$ sampai dengan $u_{23}$ sebesar 0. Derajat keanggotan maksimum terletak pada $u_{1}$ yaitu sebesar 1 dan interval $u_{1}$ adalah $[103,00,103,50)$. Berdasarkan derajat keanggotaan maksimum tersebut, maka hasil fuzzyfikasi dari suatu nilai yang berada pada interval $[103,00,103,50)$ adalah $A_{1}$. Fuzzyfikasi pada pendefinisian derajat keanggotaan $u_{i}$ terhadap $A_{i}$ lainnya mengikuti langkah-langkah sebelumnya.

\subsection{Fuzzyfikasi Data NTPT di Kalimantan Timur}

Berdasarkan derajat keanggotaan dalam pendefinisian himpunan fuzzy pada $A_{i}$ dalam proses fuzzyfikasi, maka proses fuzzyfikasi untuk data NTPT di Kalimantan Timur dari bulan Juli 2017 sampai dengan bulan Desember 2019 dapat dilihat pada Tabel 5.

Tabel 5 Fuzzyfikasi data NTPT

\begin{tabular}{lllll}
\hline No. & Tahun & Bulan & NTPT & Fuzzyfikasi \\
\hline 1 & 2017 & Juli & 104,08 & $A_{3}$ \\
2 & 2017 & Agustus & 104,56 & $A_{4}$ \\
3 & 2017 & September & 104,45 & $A_{3}$ \\
$\vdots$ & $\vdots$ & $\vdots$ & $\vdots$ & $\vdots$ \\
30 & 2019 & Desember & 111,18 & $A_{17}$ \\
\hline
\end{tabular}

Berdasarkan Tabel 5 maka diperoleh hasil fuzzyfikasi data NTPT di Kalimantan Timur dari bulan Juli 2017 sampai dengan Desember 2019. Misal, hasil fuzzyfikasi nilai NTPT di Kalimantan Timur pada bulan Juli 2017 adalah $A_{3}$. Hasil fuzzyfikasi tersebut terjadi karena nilai NTPT di Kalimantan Timur pada bulan Juli 2017 adalah 104,08. Nilai tersebut termasuk kedalam himpunan fuzzy ke-3 $\left(u_{3}\right)$ dengan interval $[104,00,104,50)$. Derajat keanggotaan maksimum yang dimiliki oleh himpunan fuzzy ke-3 $\left(u_{3}\right)$ terletak pada nilai fuzzyfikasi $A_{3}$ yaitu 1. Sehingga, hasil fuzzyfikasi nilai NTPT di Kalimantan Timur pada bulan Juli 2017 adalah $A_{3}$. Fuzzyfikasi pada bulan selanjutnya memiliki langkah-langkah yang sama seperti fuzzyfikasi pada bulan Juli 2017.

\subsection{Penentuan Fuzzy Logical Relationship (FLR)}

FLR adalah kegiatan yang dilakukan untuk menghubungkan relasi antara variabel linguistik yang ditentukan berdasarkan tabel fuzzyfikasi yang diperoleh pada Tabel 5. Hasil FLR dapat dilihat pada Tabel 6. 
Tabel 6 FLR dari Data NTPT di Kalimantan Timur

\begin{tabular}{ll}
\hline \multicolumn{1}{c}{ Bulan } & \multicolumn{1}{c}{ FLR Orde 1 } \\
\hline Juli 2017 $\rightarrow$ Agustus 2017 & $A_{3} \rightarrow A_{4}$ \\
Agustus 2017 $\rightarrow$ September 2017 & $A_{4} \rightarrow A_{3}$ \\
September 2017 $\rightarrow$ Oktober 2017 & $A_{3} \rightarrow A_{1}$ \\
$\vdots$ & $\vdots$ \\
November 2019 $\rightarrow$ Desember 2019 & $A_{16} \rightarrow A_{17}$ \\
\hline
\end{tabular}

Bulan Agustus 2017 merupakan next state $\left(D_{t}\right)$ dengan nilai fuzzyfikasi $A_{4}$. Hasil FLR yang terbentuk antara bulan Juli 2017 dengan bulan Agustus 2017 adalah $A_{3} \rightarrow A_{4}$. FLR pada bulan selanjutnya memiliki langkah-langkah yang sama seperti FLR pada bulan Juli 2017 dengan Agustus 2017.

\subsection{Penentuan Fuzzy Logical Relationship Group (FLRG)}

FLRG dilakukan dengan cara mengelompokkan fuzzyfikasi yang memiliki current state yang sama yaitu $D_{(t-1)}$ lalu dikelompokkan menjadi satu grup pada next state. Hasil FLRG secara lengkap dapat dilihat pada Tabel 7.

Tabel 7 FLRG dari Data NTPT di Kalimantan Timur

\begin{tabular}{llll}
\hline Grup & FLRG & Grup & FLRG \\
\hline 1 & $A_{1} \rightarrow A_{4}$ & 8 & $A_{17} \rightarrow A_{15}$ \\
2 & $A_{11} \rightarrow A_{9}$ & 9 & $A_{19} \rightarrow A_{22}, A_{16}$ \\
3 & $A_{12} \rightarrow A_{14}$ & 10 & $A_{22} \rightarrow A_{19}$ \\
4 & $A_{13} \rightarrow A_{15}$ & 11 & $A_{3} \rightarrow A_{4}, A_{1}$ \\
5 & $A_{14} \rightarrow A_{15}, A_{15}$ & 12 & $A_{4} \rightarrow A_{7}, A_{3}$ \\
6 & $A_{15} \rightarrow A_{15}, A_{15}, A_{19}, A_{13}, A_{16}, A_{16}, A_{16}$ & 13 & $A_{7} \rightarrow A_{11}, A_{9}$ \\
7 & $A_{16} \rightarrow A_{14}, A_{15}, A_{17}, A_{17}$ & 14 & $A_{9} \rightarrow A_{7}, A_{12}$ \\
\hline
\end{tabular}

Berdasarkan Tabel 7, semua FLR yang terbentuk pada Tabel 6 dikelompokkan menjadi FLRG yang saling berhubungan. Misal, FLRG yang terbentuk pada Grup 7 pada Tabel 7 adalah $A_{16} \rightarrow A_{14}, A_{16} \rightarrow A_{15}, A_{16} \rightarrow A_{17}$ dan $A_{16} \rightarrow A_{17} .4$ fuzzy logical relationship (FLR) tersebut dikelompokkan menjadi 1 FLRG yaitu $A_{16} \rightarrow A_{14}, A_{15}, A_{17}, A_{17}$. FLRG pada grup selanjutnya memiliki langkah-langkah yang sama seperti FLRG pada grup 1.

\subsection{Perhitungan Defuzzyfikasi Nilai Peramalan Dan Nilai MAPE Hasil Peramalan}

Pada tahap ini, fuzzy ouput akan diubah menjadi nilai tegas (numeris) untuk menghasilkan nilai peramalan. Defuzzyfikasi dilakukan dengan mengikuti 3 aturan defuzzyfikasi FTS Lee. Berdasarkan pembentukan FLRG pada Tabel 7, maka diperoleh 14 grup. Hasil defuzzyfikasi nilai peramalan dari 14 grup yang terbentuk dapat dilihat pada Tabel 8. 
Peramalan Nilai Tukar Petani Subsektor Peternakan Menggunakan ...

Tabel 8 Hasil Defuzzyfikasi Nilai Peramalan FLRG

\begin{tabular}{llll}
\hline Grup & FLRG & Persamaan & Peramalan \\
\hline 1 & $A_{1} \rightarrow A_{4}$ & $(2.10)$ & $A_{1}=104,75$ \\
2 & $A_{11} \rightarrow A_{9}$ & $(2.10)$ & $A_{11}=107,25$ \\
3 & $A_{12} \rightarrow A_{14}$ & $(2.10)$ & $A_{12}=109,75$ \\
$\vdots$ & $\vdots$ & $\vdots$ & $\vdots$ \\
& & & $A_{9}=\frac{1}{2} \times 106,25+\frac{1}{2} \times 108,75$ \\
14 & $A_{9} \rightarrow A_{7}, A_{12}$ & $(2.11)$ & $=107,50$ \\
& & & \\
\hline
\end{tabular}

Nilai peramalan akhir untuk data NTPT di Kalimantan Timur pada bulan Juli 2017 sampai dengan Desember 2019 diperoleh dari hasil defuzzyfikasi grup FLRG pada Tabel 8. Hasil peramalan dapat dilihat pada Tabel 9.

Tabel 9 Peramalan data NTPT di Kalimantan Timur

\begin{tabular}{lllll}
\hline No. & Tahun & Bulan & NTPT & Peramalan \\
\hline 1 & 2017 & Juli & 104,08 & - \\
2 & 2017 & Agustus & 104,56 & 104,00 \\
3 & 2017 & September & 104,45 & 105,25 \\
$\vdots$ & $\vdots$ & $\vdots$ & $\vdots$ & $\vdots$ \\
30 & 2019 & Desember & 111,18 & 110,62 \\
31 & 2020 & Januari & - & 110,25 \\
\hline
\end{tabular}

Berdasarkan Tabel 9 diperoleh nilai peramalan pada bulan Januari 2020 sebesar 110,25. Hasil peramalan tersebut menunjukkan bahwa petani subsektor peternakan mengalami peningkatan dalam hal perdagangan. Hal ini terjadi karena hasil peramalan NTPT di Kalimantan Timur pada bulan Januari 2020 lebih besar dari nilai 100. Langkah selanjutnya menghitung nilai MAPE hasil peramalan FTS Lee. Nilai MAPE dihitung dengan menggunakan Persamaan (12). Perhitungan nilai MAPE dapat dilihat pada Tabel 10.

Tabel 10 Perhitungan nilai MAPE hasil peramalan

\begin{tabular}{llllll}
\hline No. & Tahun & Bulan & NTPT & Peramalan & $\left|D_{t}-\hat{y}_{t}^{(m)}\right| / D_{t}$ \\
\hline 1 & 2017 & Juli & 104,08 & - & - \\
2 & 2017 & Agustus & 104,56 & 104,00 & 0,00536 \\
3 & 2017 & September & 104,45 & 105,25 & 0,00766 \\
$\vdots$ & $\vdots$ & $\vdots$ & $\vdots$ & $\vdots$ & $\vdots$ \\
30 & 2019 & Desember & 111,18 & 110,62 & 0,00504 \\
\hline \multicolumn{5}{c}{$\sum_{i=2}^{30}\left|D_{t}-\hat{y}_{t}^{(m)}\right| / D_{t}$} \\
\hline \multirow{c}{*}{ MAPE $=\left(\frac{1}{29} \sum_{i=2}^{30}\left|D_{t}-\hat{y}_{t}^{(m)}\right| / D_{t}\right) \times 100 \%$} & 0,15494 \\
\hline
\end{tabular}




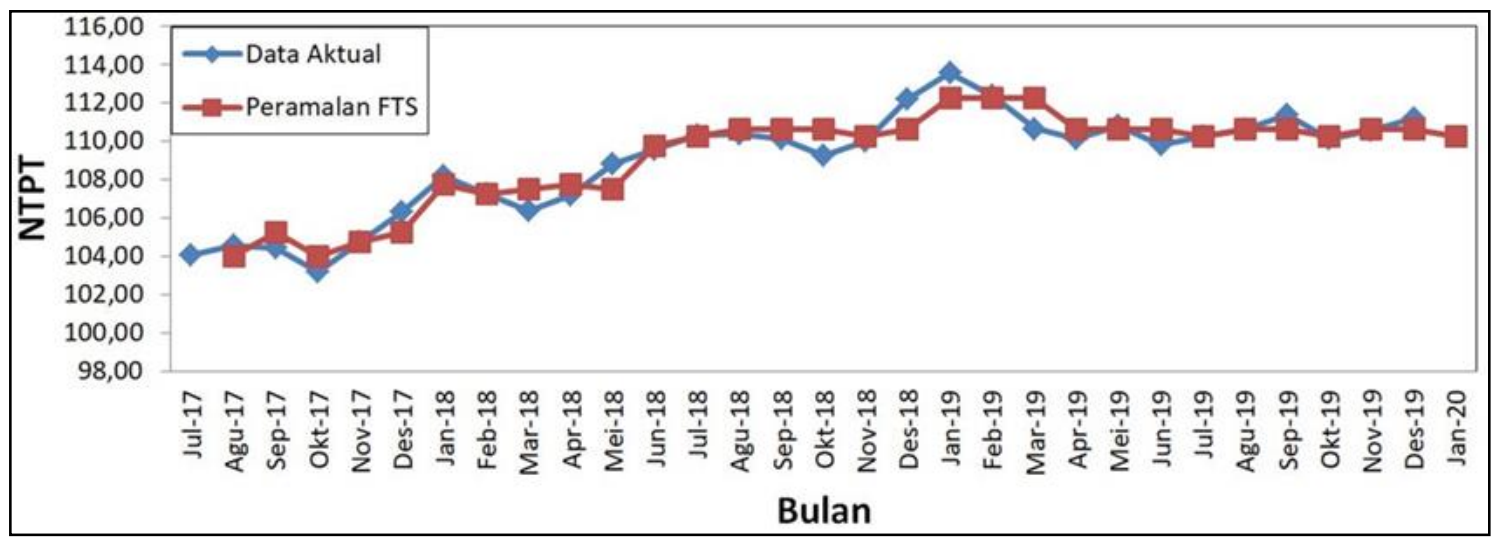

Gambar 2 Time series plot perbandingan hasil peramalan FTS Lee dengan data NTPT di Kalimantan Timur

Berdasarkan Gambar 2 dapat dilihat bahwa time series plot hasil peramalan FTS Lee cenderung mendekati time series plot data aktual NTPT di Kalimantan Timur. Berdasarkan perhitungan nilai MAPE pada Tabel 10, diperoleh nilai MAPE sebesar 0,53428\%. Nilai MAPE tersebut menunjukkan bahwa hasil peramalan NTPT di Kalimantan Timur dengan menggunakan FTS Lee adalah sangat baik karena kurang dari 10\%. Nilai MAPE yang kecil yaitu sebesar 0,53428\% disebabkan karena kesesuaian metode FTS Lee yang digunakan dengan pola data NTPT yang diperoleh. Selain itu, nilai MAPE yang yang kecil dipengaruhi karena FTS Lee memperhatikan perulangan atau tetap menghitung fuzzy logical relationship group yang sama.

\section{Kesimpulan}

Hasil peramalan data NTPT di Kalimantan Timur pada bulan Januari 2020 dengan menggunakan metode fuzzy time series Lee adalah sebesar 110,25. Hasil peramalan tersebut menunjukkan bahwa petani subsektor peternakan mengalami peningkatan dalam hal perdagangan. Hal ini terjadi karena hasil peramalan NTPT di Kalimantan Timur pada bulan Januari 2020 lebih besar dari nilai 100. Nilai MAPE dari hasil peramalan data NTPT di Kalimantan Timur dengan menggunakan metode fuzzy time series Lee adalah sebesar 0,53428\%. Nilai MAPE tersebut menunjukkan bahwa hasil peramalan data NTPT di Kalimantan Timur dengan menggunakan metode fuzzy time series Lee tergolong sangat baik karena kurang dari $10 \%$.

\section{Referensi}

[1] Aswi and Sukarna, Analisis Deret Waktu Aplikasi dan Teori. Makassar: Andira Publisher, 2006.

[2] S. Makridakis, S. C. Wheelwright, and V. E. McGree, Metode dan Aplikasi Peramalan, edisi 2. Jakarta: Erlangga, 1999.

[3] Y. Wang, Y. Lei, and Y. Wang, "Intuitionistic Fuzzy Time Series Forecasting Model Based on Intuitionistic Fuzzy Reasoning," International Journal of Mathematical Problems in Engineering., vol. 2016, pp. 1-12, 2016.

[4] A. B. Elfajar, B. D. Setiawan, and C. Dewi, "Peramalan Jumlah Kunjungan Wisatawan Kota Batu Menggunakan Metode Time Invariant Fuzzy Time Series," Jurnal Pengembangan Teknologi Informasi dan Ilmu Komputer., vol. 1, no. 2, 
pp. 85-94, 2017.

[5] W. Qiu, X. Liu, and H. Li, "A Generalized Method for Forecasting Based on Fuzzy Time Series," International Journal of Expert System with Applications., vol. 38, pp. 10446 - 10453, 2011.

[6] BPS, Statistik Nilai Tukar Petani Provinsi Kalimantan Timur. Samarinda: Badan Pusat Provinsi Kalimantan Timur, 2018.

[7] BPS Provinsi Kalimantan Timur, "Nilai Tukar Petani," 2017. [Online]. Available: https://kaltim.bps.go.id/subject/22/nilai-tukar-petani.html. [Accessed: 24Aug-2019].

[8] L. Handayani and D. Anggriani, "Perbandingan Model Chen dan Model Lee pada Metode Fuzzy Time Series untuk Prediksi Harga Emas," Jurnal Pseudocode., vol. 2, no. 1, pp. 28-36, 2015.

[9] H. Tamrin, J. Noh, and S. Hamzah, "Perbandingan Model Chen dan Model Lee pada Metode Fuzzi Time Series untuk Prediksi Jumlah Ikan," Jurnal Teknologi Informatika (J-TIFA)., vol. 5.1, no. 1, pp. 8-17, 2015.

[10] W. Istiqomah and M. Y. Darsyah, "Efektivitas Metode Arima dan Exponential Smoothing untuk Meramalkan Nilai Tukar Petani di Jawa Tengah," Prosiding Seminar Nasional Mahasiswa Unimus., vol. 1, no. 1, pp. 343-350, 2018.

[11] A. P. Desvina and I. O. Meijer, "Penerapan Model ARCH/GARCH untuk Peramalan Nilai Tukar Petani," Jurnal Sains Matematika dan Statistika., vol. 4, no. 1, pp. 43-54, 2018.

[12] Q. Song and B. S. Chissom, "Forecasting Enrollments with Fuzzy Time SeriesPart 1," International Journal of Fuzzy Sets and Systems., vol. 54, no. 1, pp. 1-9, 1993.

[13] S. Azmiyati and W. N. Tanjung, "Peramalan Jumlah Tandan Buah Segar (Tbs) Kelapa Sawit dengan Metode Fuzzy Time Series Chen dan Algoritma Ruey Chyn Tsur," Jurnal PASTI., vol. 8, no. 1, pp. 36-48, 2017.

[14] K. Nugroho, "Model Analisis Prediksi Menggunakan Metode Fuzzy Time Series," Jurnal Infokam., vol. 8, no. 1, pp. 46-50, 2016.

[15] A. Naba, Belajar Cepat Fuzzy Logic Menggunakan Matlab. Yogyakarta: Andi, 2009.

[16] S. Kusumadewi and S. Hartati, Integrasi Sistem Fuzzy E Jaringan Syaraf, edisi 2. Yogyakarta: Graha Ilmu, 2010.

[17] T. Sutojo, J. Noh, and V. Suhartono, Kecerdasan Buatan. Yogyakarta: Andi, 2010.

[18] Jumingan, Teori dan Pembuatan Proposal Kelayakan. Jakarta: PT. Bumi Aksara, 2009.

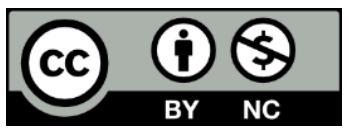

This article is an open access article distributed under the terms and conditions of the Creative Commons Attribution-NonCommercial 4.0 International License. Editorial of JJoM: Department of Mathematics, Universitas Negeri Gorontalo, Jln. Prof. Dr. Ing. B.J. Habibie, Moutong, Tilongkabila, Kabupaten Bone Bolango, Provinsi Gorontalo 96119, Indonesia. 